\title{
PENGEMBANGAN MASYARAKAT ANGGOTA BUMDES MELALUI PEMBUATAN BISKUIT BERBAHAN DASAR TEPUNG UBI KAYU DI DESA PILOBUHUTA KECAMATAN BATUDAA KABUPATEN GORONTALO
}

\section{Community Development Of Bumdes Members Through The Making Of Biscuits Based On Cassava Flour In Pilobuhuta, Batudaa Gorontalo}

\author{
Satria Wati Pade ${ }^{1)}$, Nur Fitriyanti Bulotio ${ }^{2)}$, Nurhafnita $^{3)}$,Fredy Irawan ${ }^{4)}$, Desi \\ Arisanti ${ }^{5)}$ \\ ${ }^{1,2,3,4,5)}$ Staf Pengajar Program Studi Teknologi Hasil Pertanian Politeknik Gorontalo \\ Jl. Muchlis Rahim Desa Panggulo, Kecamatan Botupingge Kabaputaen Bone Bolango, \\ Provinsi Gorontalo \\ Email : indonk@poligon.ac.id
}

\begin{abstract}
ABSTRAK
Tujuan pelaksanaan kegiatan pengabdian kepada masyarakat (PKM) ini adalah melatih keterampilan anggota BUMDES dalam melakukan pengolahan ubi kayu menjadi biscuit sehingga dapat meningkatkan pendapatan mitra. Permasalahan yang dihadapi mitra adalah keterbatasan pengetahuan dan keterampilan mengenai inovasi sehingga diperlukan adanya kegiatan pelatihan untuk menciptakan inovasi baru dalam pengembangan produk pangan. Metode pelaksanaan yang dilakukan dalam kegiatan ini adalah (1) Sosialisasi awal tentang waktu pelaksanaan kegiatan pengabdian kepada masyarakat (2) Peninjauan lokasi tempat usaha mitra, (3) Peninjauan tempat kegiatan pelatihan, (4) Identifikasi alat-alat yang dibutuhkan oleh mitra, (5) Mempersiapkan kegiatan pelatihan tentang ubi kayu, potensi dan olahannya (6) Pelaksanaan kegiatan pengabdian.
\end{abstract}

\section{Kata kunci : Ubi Kayu, Biskuit, BUMDes}

\section{ABSTRACT}

The purpose of the implementation of community service activities (PKM) is to train the skills of BUMDES members in processing cassava into biscuits so as to increase partner income. The problem faced by partners is the limited knowledge and skills regarding innovation so that training activities are needed to create new innovations in the development of food products. The implementation methods carried out in this activity are (1) Initial socialization of the time of community service activities (2) Review of the location of the partner's business, (3) Review of training activities, (4) Identification of the tools needed by partners, (5) Preparing training activities on cassava, potential and processing (6) Implementation of service activities.

Kata kunci : Cassava, Biscuit, BUMDes 


\section{PENDAHULUAN}

Kemajuan zaman sekarang ini membawa dampak begitu besar terhadap pola hidup masyarakat, mulai dari pola makan sampai dengan aktivitas fisik. Masyarakat cenderung lebih memilih makanan yang serba cepat dan praktis seperti makanan ringan atau yang sering disebut camilan. Salah satu contoh camilan adalah biskuit. Biskuit adalah produk jajanan renyah yang dibuat dengan cara dipanggang atau yang sering disebut juga sebagai kue kering (Anonim, 2018). Kue kering adalah salah satu jenis makanan ringan/kecil yang sangat digemari masyarakat Gorontalo baik di perkotaan maupun di pedesaan.

Biscuit merupakan salah satu jenis kue kering dengan bahan baku utama adalah tepung terigu. Tepung terigu terbuat dari gandum. Gandum merupakan salah satu komoditi import yang terus mengalami peningkatan setiap tahun. Salah satu cara untuk mengurangi import gandum yang terus meningkat maka diperlukan adanya alternative bahan pangan local sebagai sumber karbohidrat pengganti tepung terigu. Salah satunya bahan hasil pertanian yang dapat diolah menjadi salah satu sumber karbohidrat yaitu ubi kayu.

Berdasarkan data dari Dinas Pertanian Dan Perkebunan Kabupaten Gorontalo, tahun 2015 luas panen ubi kayu 128 ha, produksinya 1.536 ton dan produktivitas ubi kayu mencapai 120 kuintal/ha (BPS, 2018). Didaerah Gorontalo, produksi ubi kayu cukup melimpah dan mudah ditemui sebagai salah satu sumber kalori potensial yang didominasi oleh iklim kering, salah satunya di Desa Pilobuhuta Kecamatan Batudaa.

Desa pilohuhuta memiliki suatu badan usaha yang disebut BUMDes Anugerah. Salah satu fungsi utama BUMDES yaitu sebagai lembaga komersial desa yang berarti BUMDES bertujuan untuk mencari keuntungan melalui penawaran sumber daya local yang menjadi potensi desa. Jenis usaha yang bisa dikelola oleh BUMDES yaitu industry kecil dan rumah tangga yang dapat dikembangkan sesuai dengan kebutuhan potensi desa (Prasetyo, 2016). Salah satu potensi desa Pilobuhuta yaitu ubi kayu yang dapat diolah dan dijadikan sumber pendapatan BUMDes.

Masyarakat yang tinggal diwilayah kabupaten Gorontalo, desa Pilobuhuta Kecamatan Batudaa biasanya hanya mengolah ubi kayu sebatas olahan sederhana seperti direbus ataupun digoreng sehingga menimbulkan kejenuhan mengkonsumsi olahan ubi kayu padahal ubi kayu memiliki segudang manfaat selain sebagai sumber kalori seperti kadar serat pangan yang cukup tinggi. Oleh sebab itu diperlukan inovasi dalam hal pengolahan ubi kayu, salah satunya diolah menjadi biscuit sehingga olahan ubi kayu yang banyak manfaat dapat dinikmati oleh semua kalangan masyarakat tanpa menghilangkan konsep praktis dan cepat dari biscuit itu sendiri.

Keterampilan pengolahan ubi kayu menjadi biscuit dapat disalurkan melalui kegiatan-kegiatan pelatihan. Kegiatan pelatihan pada ibu-ibu kelompok BUMDES (Badan Usaha Milik Desa) menjadi hal yang sangat penting agar dapat menghasilkan SDM yang lebih berkualitas dan menghasilkan inovasi baru dalam bidang pangan. Dengan begitu, diharapkan ilmu yang diterima dapat dikembangkan menjadi wirausaha. Dengan adanya jalinan kerjasama maka diharapkan dapat terciptanya sinergi antara pihak kampus dengan pihak BUMDES Desa Pilobuhuta Kecamatan Batudaa sehingga kesejahteraan anggota ibu-ibu anggota BUMDES dan masyarakat setempat bisa terwujud melalui serangkain kegiatan pelatihan. 
Ibu - ibu kelompok BUMDES merupakan salah satu SDM yang bisa diandalkan untuk menciptakan berbagai produk inovasi dibidang pangan yang dapat dimanfaatkan oleh masyarakat umum. Akan tetapi, keterbatasan pengetahuan dan keterampilan mengenai inovasi menjadi salah satu hambatan sehingga diperlukan adanya kegiatan pelatihan untuk menciptakan inovasi baru terutama dalam pengembangan produk pangan.

Tujuan dari pelaksanaan kagiatan pengabdian ini adalah untuk melatih keterampilan anggota BUMDES dalam melakukan pengolahan ubi kayu menjadi biscuit sehingga dapat meningkatkan pendapatan mitra BUMDes

\section{METODE}

Metode pelaksanaan pada kegiatan ini adalah dengan memberikan materi pengantar terlebih dahulu dalam bentuk audio visual kepada para peserta yang dilengkapi panduan tahapan proses pengolahan biscuit ubi kayu. Peserta dibagi dalam 5 kelompok terdiri dari 5 orang anggota. Setiap kelompok melakukan praktek langsung setelah mendapatkan materi dan arahan dari narasumber. Pada saat praktek berlangsung, kelompok peserta akan didampingi oleh pendamping yang telah dibagi sebelumnya.

Metode kegiatan yang akan dilakukan untuk tercapainya tujuan Pengabdian Kepada masyarakat ini adalah metode ceramah, diskusi dan praktek langsung. Demonstrasi praktek langsung di lapangan yang didasari oleh evaluasi awal sebagai landasan untuk menentukan permasalahan dan metode yang tepat yang kemudian akan dilakukan evaluasi untuk melihat keberhasilan pencapaian tujuan.

Tahapan pelaksanaan kegiatan yaitu :

1. Sosialisasi awal tentang waktu pelaksanaan kegiatan pengabdian kepada masyarakat (PKM) pada anggota BUMDes Anugerah.

2. Peninjauan lokasi tempat usaha mitra pengabdian

3. Peninjauan tempat untuk kegiatan pelatihan kepada mitra pengabdian yang berlokasi disekretariat BUMDes.

4. Identifikasi alat-alat yang dibutuhkan oleh mitra pengabdian

5. Mempersiapkan kegiatan pelatihan kepada mitra pengabdian tentang ubi kayu, potensi dan olahnnya.

6. Melaksanakan kegiatan pengabdian dalam bentuk pelatihan.

\section{HASIL DAN PEMBAHASAN}

Hasil dari beberapa tahapan pelaksanaan pada kegiatan PKM sebagai berikut:

1. Meningkatnya pengetahuan mitra mengenai diversifikasi olahan ubi kayu. Sebelum kegiatan PKM diadakan, mitra hanya menjual ubi kayu dalam bentuk segar dan dikonsumsi sendiri dengan cara diolah direbus, digoreng dan diolah menjadi panganan tradisional, padahal ubi kayu memiliki potensi untuk diolah menjadi produk olahan yang lebih bernilai ekonomis. Oleh karena itu kegiatan perdana yang dilakukan adalah transfer ilmu berupa penyajian materi tentang ubi kayu, olahan dan potensinya dalam bentuk presentasi powerpoint dan dilengkapi modul. Beberapa kelebihan yang dimiliki oleh mitra adalah sumberdaya alam berupa ubi kayu yang cukup melimpah, tersedianya tenaga kerja, tanaman ubi kayu mudah tumbuh di berbagai kondisi dibandingkan dengan tanaman lain. Akan tetapi, komoditas ubi kayu di Kecamatan Batudaa masih memiliki beberapa kelemahan yaitu tingkat produktivitas hasil pertanian yang masih rendah, minimnya produk turunan hasil ubi kayu. Hasilnya dari kegiatan pelatihan ini adalah para mitra termotivasi untuk memberikan nilai tambah pada produk ubi kayu yang selama 
ini hanya diolah sebatas penganan tradisional tanpa ada sentuhan teknologi.

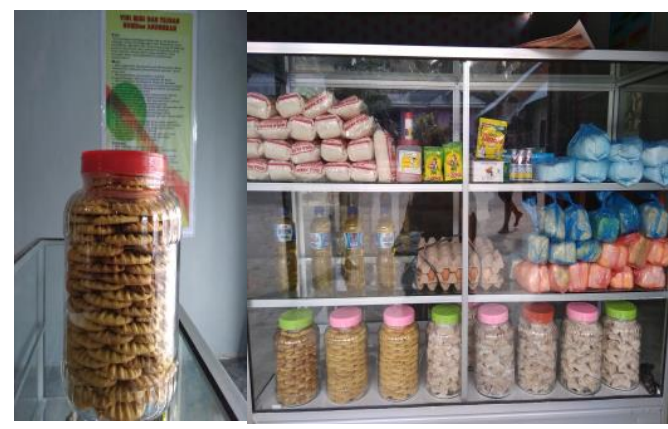

Gambar 1. Kegiatan Pengabdian

2. Ada beberapa kendala yang dihadapi yakni : Jarak dan kesibukan mitra sebagai ibu rumah tangga sehingga waktu yang disediakan untuk mengikuti pelatihan terbatas, akan tetapi beberapa ibu-ibu anggota BUMDes tetap semangat mengikuti kegiatan. Kendala lainnya yaitu proses pembuatan tepung ubi kayu sebagai bahan dasar pembuatan biscuit, memakan waktu yang cukup lama karena proses pengeringannya membutuhkan waktu sekitar 3-4 hari agar benar-benar kering, sehingga disiasati, sebelum pelaksnaan pelatihan inti berlangsung, tepung ubi kayu sudah dipersiapkan oleh mitra beberapa hari sebelum pelaksanaan pelatihan.

Tepung ubi kayu yang sudah ada kemudian diolah menjadi biscuit ubi kayu bersama dengan mitra sambil didampingi oleh tenaga pendamping pelatihan. Produk ubi kayu kemudian dikemas dengan menggunakan kemasan tradisional berupa toples kaca yang cukup berat dan mudah pecah yang sudah disediakan oleh mitra. Sehubungan dengan hal tersebut, tim pengabdian menyarankan kepada mitra agar membuat kemasan yang lebih menarik sehingga bisa menambah daya jual dari produk. Selain sebagai pelindung produk, kemasan juga berfungsi sebagai penambah daya tarik calon pembeli,
Sarana informasi dan iklan dan memberi kenyamanan bagi pemakai (Julianti dan Nurminah, 2006). Selain kemasan, diperlukan juga teknik pemasaran yang tepat sehingga dapat meningkatkan pendapatan mitra. Untuk itu, diharapkan adanya pelatihan lanjutan terkait dengan hal tersebut.

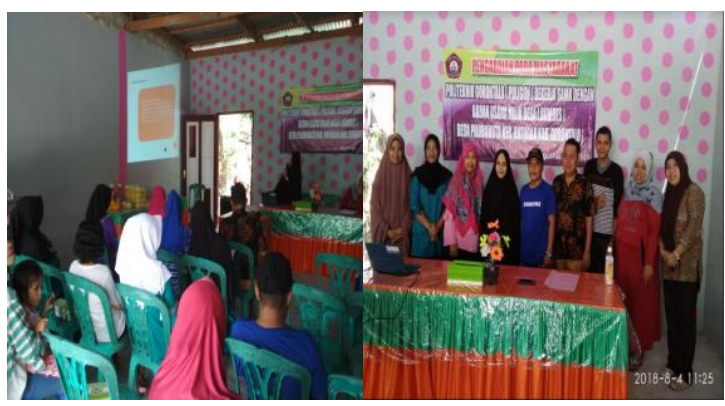

Gambar 2. Produk Biskuit Ubi Kayu

\section{KESIMPULAN}

Kesimpulan pada kegiatan pengabdian ini antara lain :

1. Terjalinnya kerjasama dengan pihak BUMDES melalui kegiatan pelatihan yang dapat menjadi sarana informasi dan pengembangan keterampilan.

2.Peningkatan motivasi untuk mengembangkan potensi desa melalui BUMDEs sebagai salah satu unit dibawah koordinasi pemerintah desa dengan sentuhan kreatifitas, meningkatnya pengetahuan dan ketrampilan mitra dalam mengolah ubi kayu menjadi biscuit salah satu produk unggulan sebagai oleh-oleh camilan khas Gorontalo sehingga dapat membantu perekonomian Ibu-Ibu anggota BUMDes dan masyarakat sekitar khususnya di daerah kecamatan Batudaa

\section{UCAPAN TERIMA KASIH}

Ucapan terima kasih disampaikan kepada Yayasan Pengembangan Sumber Daya Manusia (YPPSDM) Gorontalo dan Direktur Politeknik Gorontalo yang telah mendanai kegiatan ini dalam hibah dana 
Pengabdian Kepada Masyarakat Tahun 2018.

\section{DAFTAR PUSTAKA}

Badan Pusat Statistik Provinsi Gorontalo. Luas Panen dan Produksi Ubi Kayu dan Ubi Jalan, 2018

Julianti, E dan M. Nurminah. 2006. Teknologi Pengemasan. Fakultas Pertanian Universitas Sumatera Utara.

Prasetyo, R. A. 2016. Peranan Bumdes Dalam Pembangunan Dan Pemberdayaan Masyarakat Didesa Pejambon Kecamatan Sumberrejo Kabupaten Bojonegoro. Jurnal Dialektika Volume XI. No.1 Tahun 2016. 